\title{
Lucian Blaga Between Words and Silence
}

\section{Rodica Grigore ${ }^{1}$}

One of the most important Romanian writers of the interwar period, Lucian Blaga (1895 - 1961) has been well known as a poet and a philosopher, an exquisite translator, a subtle essayist and a valuable playwright. His early poems express the spirit of a specific and personal type of Expressionism, while his later ones illustrate an even more skeptical attitude towards reality, underlying different sides of Blaga's philosophy. In Blaga's mature poetic world the mythic fertility of the beginnings has left an all encompassing mark in which the poet has found his true and unique home, hence the innovative imagery he uses within his creation. [Article copies available for a fee from The Transformative Studies Institute. E-mail address: journal@transformativestudies.org Website: http://www.transformativestudies.org (C2015 by The Transformative Studies Institute. All rights reserved.]

KEYWORDS: Modern Poetry, Expressionism, Philosophical Discourse, Mythic Imagery.

\footnotetext{
${ }^{1}$ Rodica Grigore, Ph.D., is senior lecturer in Comparative Literature at "Lucian Blaga" University of Sibiu, Romania. She is the author of five critcal studies: Despre cărţi şi alţi demoni [Of Books and Other Demons, 2002], Retorica măştilor în proza interbelică românească [The Rhetoric of Masks in Romanian Modern Fiction, 2005], Lecturi in labirint [Readings in the Labyrinth, 2007], Măști, caligrafie, literatură [Masks, Calligraphy, Literature, 2011], In oglinda literaturii [In the Mirror of Literature, 2011], Meridianele prozei [Fiction's Meridians, 2013], Pretextele textului [The Pretexts of the Text, 2014]. She has also translated into Romanian the essays of Octavio Paz, Copiii mlaştinii [Children of the Mire, 2003], the poems of the Colombian writer Manuel Cortés Castañeda, Oglinda celuilalt [The Mirrored Other, 2006] and a collection of novellas and short stories of the American writer Andrei Codrescu, Un bar din Brooklyn [A Bar in Brooklyn, 2006]. Between 2005 and 2012 she has been coordinating the anthology of The International Theatre Festival of Sibiu. She has published numerous essays and critical studies especially on modern literature in several Romanian literary magazines: Cultura, Observator Cultural, Euphorion, Scrisul Românesc, Viaţa Românească etc. She is also known as a translator from English, French and Spanish, and recently she has authored a short anthology of Romanian poetry published in Mexico, Spain, Perú, Venezuela and Argentina. Address correspondence to: Rodica Grigore; e-mail: rodica.grigore@gmail.com.
} 